US Army Corps

of Engineers

Waterways Experiment

Station

\title{
Magnitude-Frequency Analysis of Sediment Transport in the Lower Mississippi River
}

by David S. Biedenharn, WES

Charles D. Little, Vicksburg District

Colin R. Thorne, University of Nottingham

Approved For Public Release; Distribution Is Unlimited 
The contents of this report are not to be used for advertising, publication, or promotional purposes. Citation of trade names does not constitute an official endorsement or approval of the use of such commercial products.

The findings of this report are not to be construed as an official Department of the Army position, unless so designated by other authorized documents. 


\section{Magnitude-Frequency Analysis of Sediment Transport in the Lower Mississippi River}

by David S. Biedenharn

U.S. Army Corps of Engineers

Waterways Experiment Station

3909 Halls Ferry Road

Vicksburg, MS 39180-6199

Charles D. Little

U.S. Army Corps of Engineers

Vicksburg District

P.O. Box 60

Vicksburg, MS 39180-6199

Colin R. Thorne

Department of Geography

Unversity of Nottingham

Nottingham, NG7 2RD, UK

Final report

Approved for public release; distribution is unlimited 


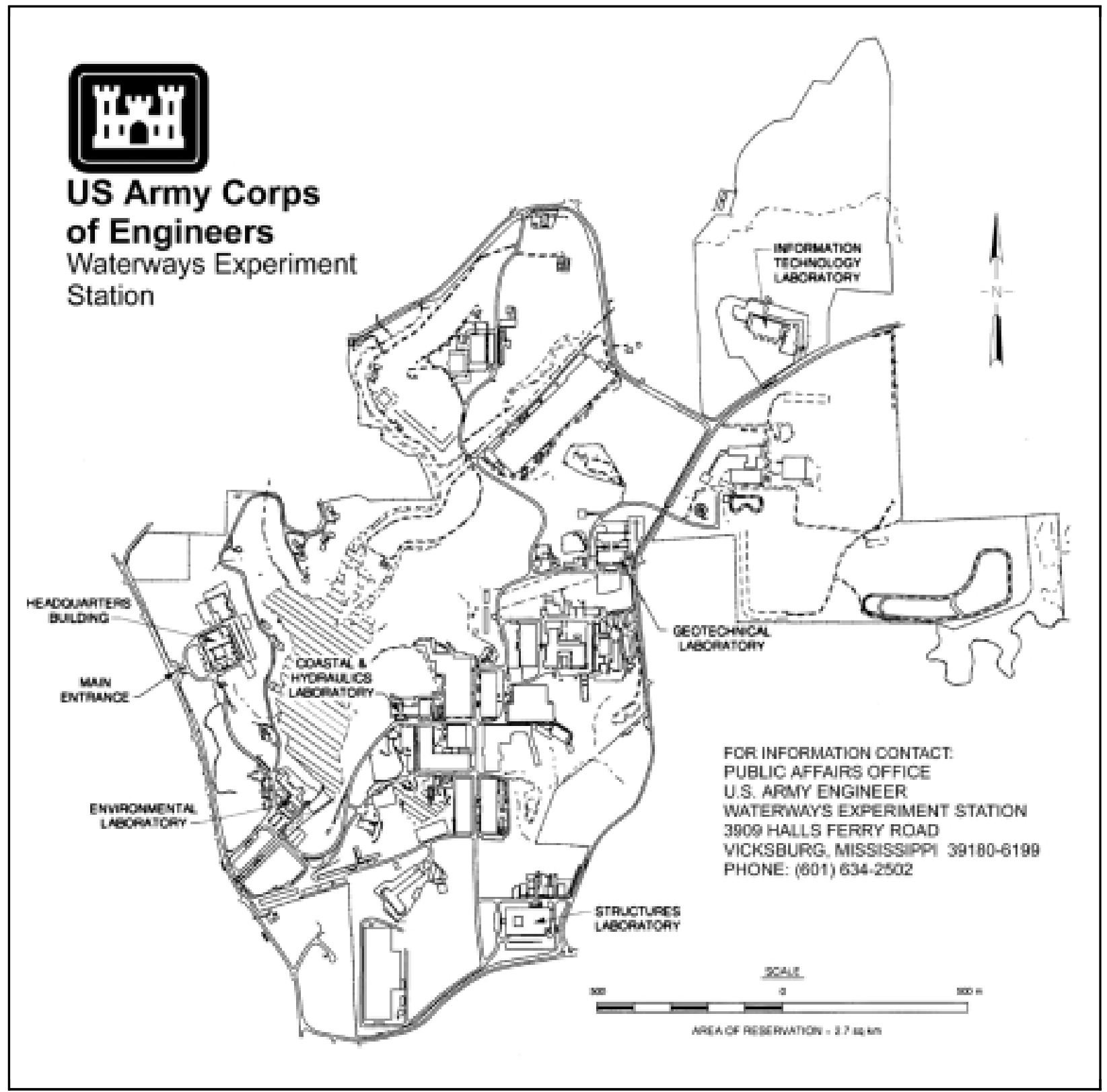

Waterways Experiment Station Cataloging-in-Publication Data

Biedenharn, David S.

Magnitude-frequency analysis of sediment transport in the lower Mississippi River / by David S. Biedenharn, Charles D. Little, Colin R. Thorne ; prepared for U.S. Army Corps of Engineers.

31 p. : ill. ; $28 \mathrm{~cm}$. - (Miscellaneous paper ; CHL-99-2)

Includes bibliographic references.

1. Sediment transport - Mississippi River. 2. Mississippi River - Sedimentation and deposition. 3. Sedimentation and deposition - Mississippi River. I. Little, Charles D. II. Thorne, C. R. (Colin R.) III. United States. Army. Corps of Engineers. IV. U.S. Army Engineer Waterways Experiment Station. V. Coastal and Hydraulics Laboratory (U.S. Army Engineer Waterways Experiment Station) VI. Title. VII. Series: Miscellaneous paper (U.S. Army Engineer Waterways Experiment Station) ; CHL-99-2.

TA7 W34m no.CHL-99-2 


\section{Contents}

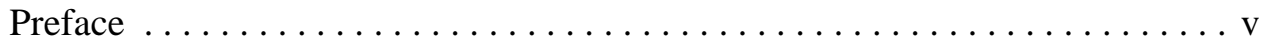

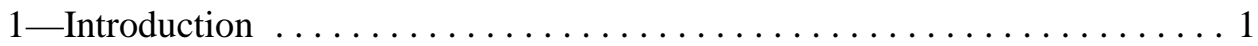

2 -Study Area $\ldots \ldots \ldots \ldots \ldots \ldots \ldots \ldots \ldots \ldots \ldots \ldots \ldots \ldots \ldots \ldots \ldots \ldots \ldots \ldots \ldots$

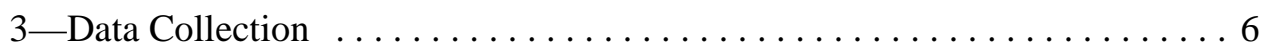

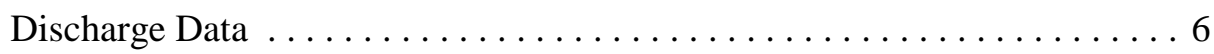

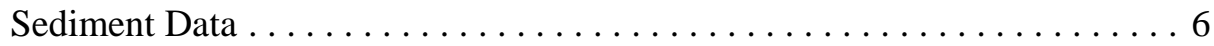

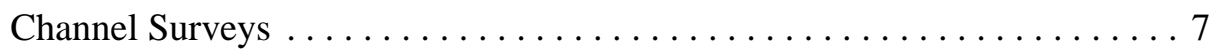

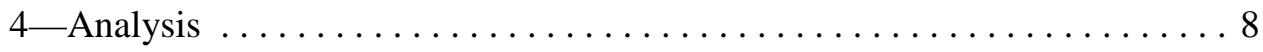

Magnitude-Frequency Calculations $\ldots \ldots \ldots \ldots \ldots \ldots \ldots$

Determination of Top of Bank and Mid-Channel Bar Elevations . . . . . 10

5-Discussion ................................ 14

Effective Discharge Analyses . . . . . . . . . . . . . . . . . . . . . 14

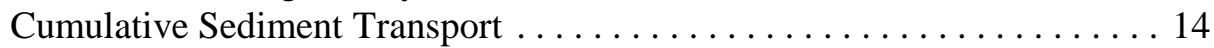

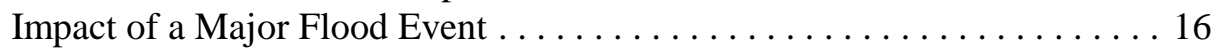

Morphological Expressions of the Dominant Discharge and Effective

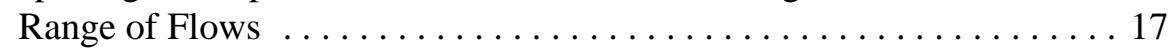

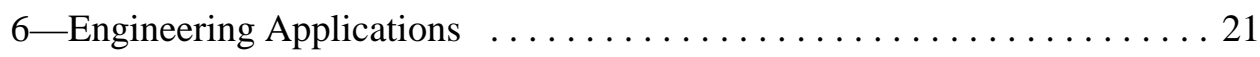

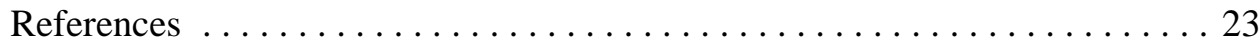

SF 298

\section{List of Figures}

Figure 1. Alluvial valley of the Mississippi $\ldots \ldots \ldots \ldots \ldots \ldots$

Figure 2. Flow duration curve for Vicksburg, Mississippi 1950-1982 . . . 7

Figure 3. Sediment rating curves for the period 1969-1979 at

(a) Arkansas City, (b) Vicksburg, and (c) Natchez ......... 9 
Figure 4. Dominant discharge distributions for time period 1950-1982 for (a) Arkansas City, (b) Vicksburg, and (c) Natchez ........ 11

Figure 5. Cumulative sediment load curves for time period 1950-1982 for (a) Arkansas City, (b) Vicksburg, and (c) Natchez . . . . . . 12

Figure 6. Area-elevation curve for a typical mid-channel bar in the study reach. Data taken from Kentucky Bar at river kilometer 840 for 1988-1989 hydrographic survey . . . . . . . . . 13

Figure 7. Water surface profiles for selected discharges in the Lower Mississippi River ....................... 15

Figure 8. Dominant discharge distributions for Natchez including the Corps of Engineer's Project Flood . . . . . . . . . . . . 16

Figure 9. Cumulative sediment load curve for Natchez including the Corps of Engineers' Project Flood . . . . . . . . . . . 17

Figure 10. Long-channel variation in top-bank elevations in the

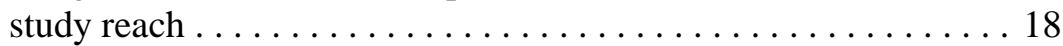

Figure 11. Long-channel variation in elevations of mid-channel bars in the study reach . . . . . . . . . . . . . . . . . . 19 


\section{Preface}

The research reported herein was undertaken at the offices of the U.S. Army Engineer District, Vicksburg, and the U.S. Army Engineer Division, Lower Mississippi Valley, both located in Vicksburg, Mississippi.

This report was written by Dr. David S. Biedenharn, Coastal and Hydraulics Laboratory (CHL), U.S. Army Engineer Waterways Experiment Station, Vicksburg, MS, a complex of five laboratories of the U.S. Army Engineer Research and Development Center (ERDC); Mr. Charles D. Little, U.S. Army Corps of Engineers, Vicksburg District; and Dr. Colin R. Thorne, Department of Geography, University of Nottingham, United Kingdom. Dr. Biedenharn worked under the general supervision of Dr. Phil Combs, Chief, Rivers and Structures Division, CHL; and Dr. James R. Houston, Director, CHL.

Commander of ERDC during preparation and publication of this report was COL Robin R. Cababa, EN. This report was prepared and published at the WES complex of ERDC.

The contents of this report are not to be used for advertising, publication, or promotional purposes. Citation of trade names does not constitute an official endorsement or approval of the use of such commercial products. 


\section{Introduction}

Natural, alluvial rivers experience a wide range of discharges and adjust their shape and size to each flow event that mobilizes either bed or bank sediments. Until the 1960s it was widely assumed that it was floods of great magnitude, but low frequency, that controlled channel form because of the nonlinear relationship between discharge and sediment transport capacity in which sediment load increases according to about the 1.5 power of stream power (Bagnold 1966). Consequently, the largest floods have enormous potential to transport sediment and to alter channel morphology radically. This view was challenged by Wolman and Miller (1960), who demonstrated that over an extended period of time, the total amount of sediment transported (and therefore work done in forming the channel) by a flow of a given magnitude depends not only on its transport capacity, but also its frequency of occurrence. Thus, although extremely large events can produce spectacularly high sediment loads, they happen so infrequently and last such a short time that their overall contribution to sediment movement during a long period is relatively small. Small events also make a small contribution to the total sediment moved because their high frequency of occurrence is offset by their very low sediment transport capacity. It follows from this logic that it is flows of moderate magnitude and frequency that are responsible for the greatest amount of sediment movement.

Wolman and Miller defined 'moderate frequency' as events occurring 'at least once each year or two and in many cases several or more times per year' (Wolman and Miller 1960:p.60). They also considered the sediment load transported by a given flow as a percentage of the total amount of sediment carried by the river during the period of record and then added the results from small to large events to find the percentage of the sediment load carried by events less than or equal to a given discharge. Their results, for a variety of American rivers located in different climatic and physiographic regions, showed that the greater part (that is, 50 percent or more) of the total sediment load was carried by moderate flows rather than catastrophic floods. Further to this, 90 percent of the load was carried by events with a return period of less than 5 years. The precise form of the cumulative curve actually depends on factors such as the predominant mode of transport (bed load, suspended load, or dissolved load) and the flow variability, which is influenced by catchment size. Small catchments generally experience a wider range of flows than large catchments and this tends to increase the proportion of sediment load carried by infrequent events. 
On the basis of both theoretical and empirical arguments, bank-full discharge is generally recognized as being the moderate flow that best fits Wolman and Miller's dominant discharge concept for rivers in dynamic equilibrium. This is the flow that just fills the channel, without overtopping the banks. Although Wolman and Miller noted that 'it is logical to assume that the channel shape is affected by a range of flows rather than a single discharge' (Wolman and Miller 1960: p. 65), they concurred with the view put forward earlier by civil engineers working on 'regime theory' that the dominant discharge is the steady flow that produces the same gross channel shapes and dimensions as the natural sequence of events (Inglis 1949). This has been shown to be bank-full discharge for planform attributes such as meander wavelength (Ackers and Charlton 1970) and cross-sectional morphology (Hey 1972; 1982).

In a river confined by levees and trained by revetments and contraction works, lateral channel migration and flow interactions between the channel and floodplain are prevented. The equivalent morphological expression of dominant flow in such instances might be the height of mid-channel and point bars, because their elevations are adjusted through lateral reworking of the bar sediments whereas the possibility of reworking the valley-fill sediments is denied to the river (Lewin 1978). However, this concept has not yet been tested using data from a trained river.

Field identification of bank-full discharge causes problems (Williams 1978), but is usually based on a minimum width-to-depth ratio ( Wolman 1955), together with the recognition of some discontinuity in the nature of the channel such as a change in its sedimentary or vegetative characteristics. This approach should also be appropriate for a trained river, but with the cross-profiles and vegetation on channel bars providing much of the evidence normally gathered from the floodplain.

For stable alluvial channels in dynamic equilibrium, the return period for bank-full flow has been identified as being in the range 1 to 2 years (Wolman and Leopold 1975). Hey (1975) showed that for three British gravel-bed rivers, the 1.5-year flood in an annual maximum series passed through the scatter of bank-full discharges measured along the course of the rivers. He went on to demonstrate using a magnitude-frequency analysis that the 1.5 -year flood was equivalent to the dominant discharge. Richards (1982) suggests that in a partial duration series, bank-full discharge equals the most probable annual flood, which has a 1-year return period.

Although the dominant discharge concept is not universally accepted, most river engineers and scientists agree that the concept has merit, at least for relatively large catchments, in humid areas, and over periods of 30 years or more. Thorough reviews of arguments about the conceptual basis of dominant discharge theory may be found in textbooks by Richards (1982), Knighton (1984), and Summerfield (1991). However, there have been relatively few applications of magnitude-frequency analysis to large rivers owing to the difficulties of obtaining reliable data over significantly long periods of record. In an earlier paper such data were examined for the Red, Pearl, and Lower Mississippi Rivers 
in the southeastern United States. (Biedenharn, Little, and Thorne 1987). This paper presents a more extensive examination of the data for the largest and most important of these rivers, the Lower Mississippi. The results of the analysis have immediate implications for river engineering and management, and these are explored briefly. 


\section{Study Area}

The Mississippi River originates in Lake Itasca, Minnesota, and flows through the central United States for 3,760 km to its mouth in the Gulf of Mexico, about $185 \mathrm{~km}$ downstream of New Orleans, Louisiana (Figure 1). The total drainage area of the Mississippi River and its tributaries is $2,975,910 \mathrm{~km}^{2}$, which constitutes 41 percent of the continental United States. The alluvial valley of the Lower Mississippi River begins just below Cape Girardeau, Missouri, where the floodplain widens abruptly, varying in width from 48 to $200 \mathrm{~km}$ (Figure 1). Historically, this area was inundated during periods of high flows, but today it is mostly protected by levees that confine the flood flows within a floodplain with an average width of only $8 \mathrm{~km}$. High-water and flood stages usually occur in the late winter and early spring, whereas the low-water season generally extends from about August to December. Unlike the Upper Mississippi River, the Lower Mississippi River did not experience severe flooding during the summer of 1993 because of its much larger channel capacity.

The study limits for this analysis extend from about river kilometer 976 to river kilometer 512 (Figure 1). River kilometers are measured upstream from the head of passes (AHP) at the Gulf of Mexico. Figure 1 also shows the three main gauging stations for this reach. The mean annual flow of the Mississippi is about $17,000 \mathrm{~m}^{3} / \mathrm{s}$, and the highest recorded discharge is $61,140 \mathrm{~m}^{3} / \mathrm{s}$. In the study reach, the river is predominantly sand-bedded, with a median grain size of approximately $0.38 \mathrm{~mm}$. However, there are localized areas of gravel. The slope varies from about 0.000052 near Natchez to 0.00008 near Arkansas City. The average annual measured sediment load passing through the reach is about $140 \times 10^{6}$ tons, of which, on average, about 70 percent is fine sediment (silt) with particle sizes less than $0.062 \mathrm{~mm}$.

During the last 50 years the river has responded to a variety of natural and human-induced changes. To provide adequate flood control and navigation, the U.S. Army Corps of Engineers has constructed numerous channel improvement features throughout the basin. Within the study area, the principal features include levees, bank revetments, cut-offs, dikes, and dredging. The river response was most marked after the bend cut-off program of the 1930s and 1940s, with river levels lowered by as much as $4.8 \mathrm{~m}$ at the Arkansas City gauge. Although lowering is still occurring in the upper reaches of the study area, 


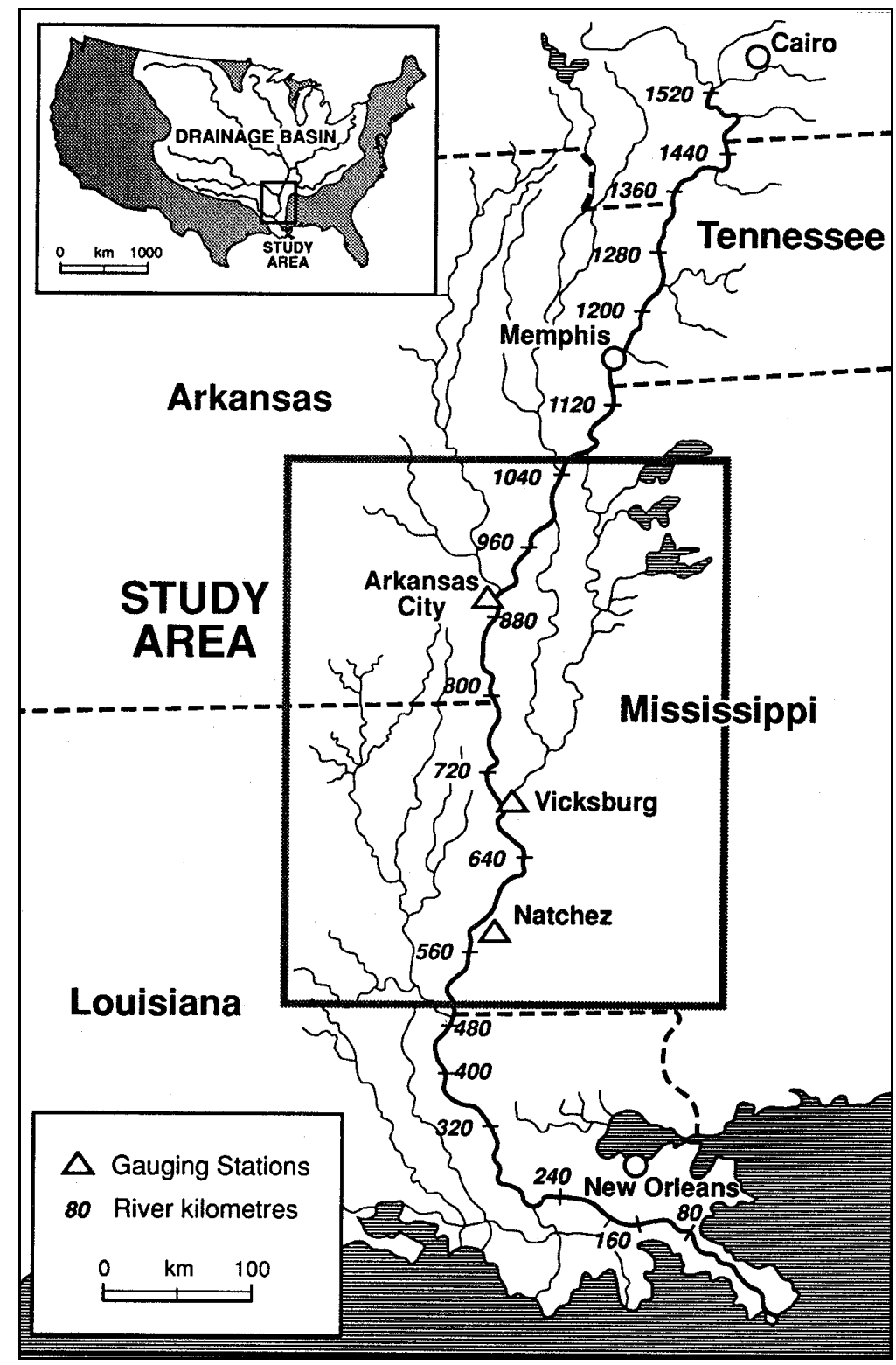

Figure 1. Alluvial valley of the Mississippi

records from the Vicksburg and Natchez gauges indicate that bed levels in the middle to lower reaches have not stabilized. 


\section{Data Collection}

\section{Discharge Data}

Mean daily discharge data were obtained from the Arkansas City, Vicksburg, and Natchez gauging stations covering a period of record from 1950 to 1982. This period was selected because it encompasses the period when sediment loads were routinely measured at each gauging station. On small rivers, instantaneous discharges may differ significantly from the mean daily flows, but on a very large system such as the Lower Mississippi River, the two are actually very similar. The record contains a wide distribution of flows, including both extremely low and high flow years. Observed discharges range from a low of about $4,250 \mathrm{~m}^{3} / \mathrm{s}$ to a high just over $56,600 \mathrm{~m}^{3} / \mathrm{s}$ during the 1973 flood. Flow duration curves for 1950-1982 were developed for all three stations. Figure 2 is the flow duration curve for the Vicksburg gauging station. The duration curves for the other two stations are very similar and are therefore not shown.

\section{Sediment Data}

Sediment transport data were also obtained from the Arkansas City, Vicksburg, and Natchez gauging stations. The period of record is 1969 to 1979, as this was the only period for which measured sediment transport records were available. On average, sediment was measured at each station about once a week during that period. The period of record includes several large flows of long duration so that the data include both high and low flow conditions. Robbins (1977) provides a detailed description of the suspended sediment measurement program on the Lower Mississippi River. The measured sediment load is divided into two components: (a) fine sediment load consisting of particles less than $0.062 \mathrm{~mm}$, and (b) sand load with particles greater than $0.062 \mathrm{~mm}$. The total measured sediment load is the sum of these two components.

As the fine sediment constitutes the 'wash load,' which is generally transported through the system and has very little impact on the shaping of the channel, it was decided to use only the measured sand load in this analysis. The 


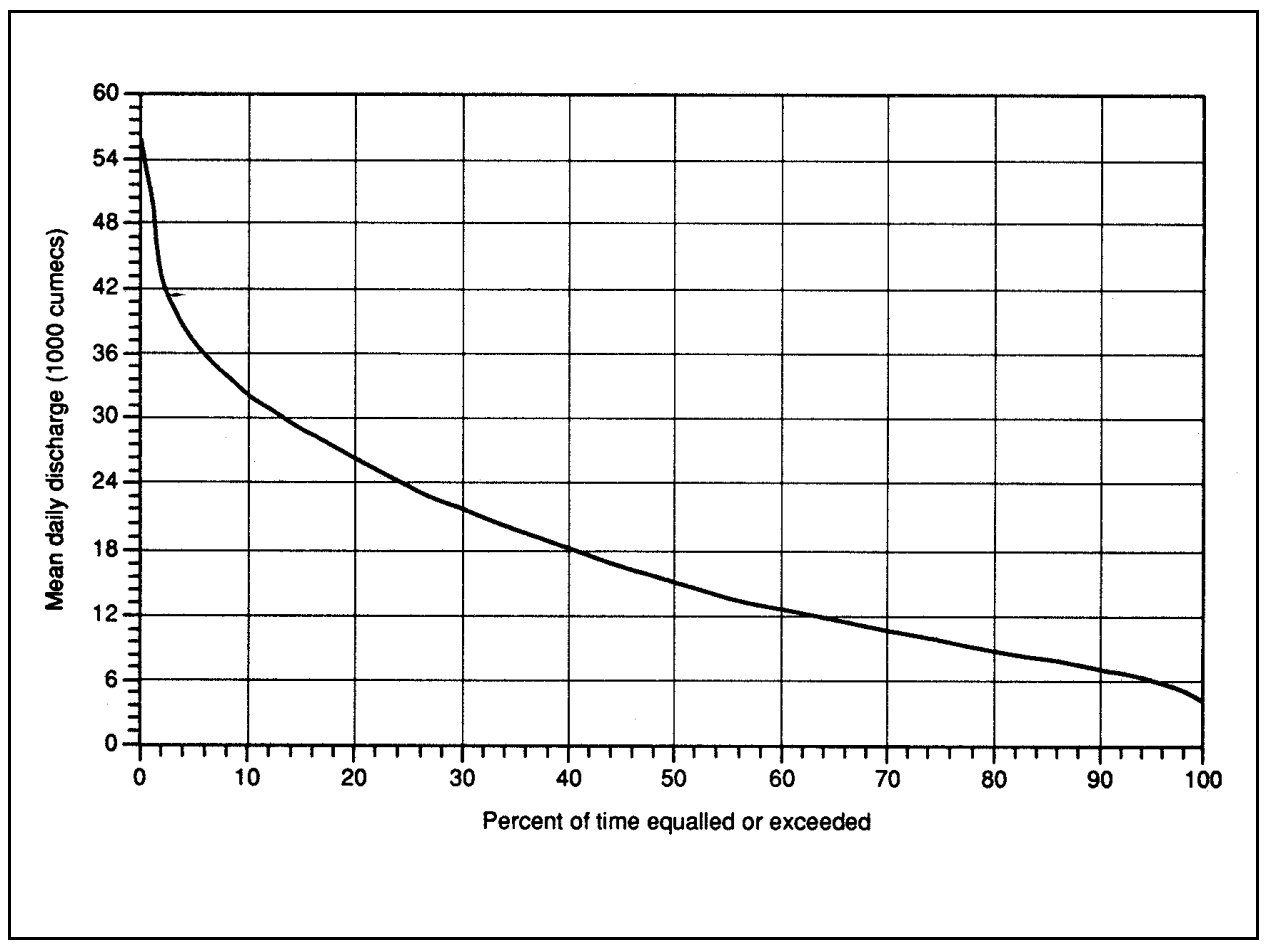

Figure 2. Flow duration curve for Vicksburg, Mississippi 1950-1982

measured sand load should correspond closely to the suspended bed material load, which plays an important part in shaping the channel. However, the measured sand load does not reflect the bed material that is transported as bed load. Although there are no measurements of the bed load discharge on the Mississippi River, according to the calculations of Toffaleti (1968), the bed load comprises less than 5 percent of the total sand discharge. Thus the term 'sediment load' used in this paper refers to the measured sand load.

To evaluate the impact of excluding wash load, the analysis was repeated using the total measured sediment load. This showed that although the absolute amount of sediment moved changed in comparison to the sand load results, the shape of the curves and the location of the major peak defining the dominant discharge were unchanged. Similar results were reported by Thorne, Russell, and Alan (1993) for the Brahmaputra River, suggesting that this finding is not unique to the Lower Mississippi.

\section{Channel Surveys}

Top of bank and mid-channel bar elevations were determined to relate the morphology of the river to the dominant flows identified in the magnitudefrequency analysis. The elevations of these features were determined from hydrographic surveys made in 1962-1964, 1973-1975, and 1988-1989. These were comprehensive surveys with cross sections surveyed about every $300 \mathrm{~m}$ along the channel. 


\section{Analysis}

\section{Magnitude-Frequency Calculations}

The first step in the magnitude-frequency procedure was to group the mean daily discharge data into flow increments and determine the number of events occurring in each increment over the entire period of record. A range of flow increments from $140 \mathrm{~m}^{3} / \mathrm{s}$ up to $6,000 \mathrm{~m}^{3} / \mathrm{s}$ was tested to determine the increment that was small enough to accurately establish the dominant discharge, yet large enough to produce a relatively smooth curve. Based on these tests, a flow increment of $1,000 \mathrm{~m}^{3} / \mathrm{s}$ was selected.

Sediment rating curves were developed for each gauging section. These curves are shown in Figure 3. After several curve-fitting techniques were tested against the data, it was found that a double logarithmic regression provided the best fit. The relationship for each station is of the form of a power law.

$$
Q_{s}=a_{Q} b
$$

where $Q_{s}=$ measured sand load ( $/$ day), $Q=$ discharge $\left(\mathrm{m}^{3} / \mathrm{s}\right), a=$ a coefficient, and $b=$ an exponent. Values for the coefficient, exponent, and $r^{2}$ for each station are listed in Table 1.

As indicated by the $r^{2}$ values in Table 1, the curves for the Natchez and Vicksburg stations describe the relationship between discharge and sediment load reasonably well. The fit is poorer for the Arkansas City station, although the correlation coefficient is still statistically significant. The poor fit may be due to the scarcity of data points for flows above $30,000 \mathrm{~m}^{3} / \mathrm{s}$, the effect of the instability of the gauge due to the continued water level lowering in this reach, and the greater variability resulting from silting of the measurement section, which is at a meander crossing rather than a pool section, as at both Vicksburg and Natchez.

Using the sediment rating equations, the sediment load associated with each flow increment was calculated. The total amount of sediment transported in each flow increment over the entire period of record was determined by 


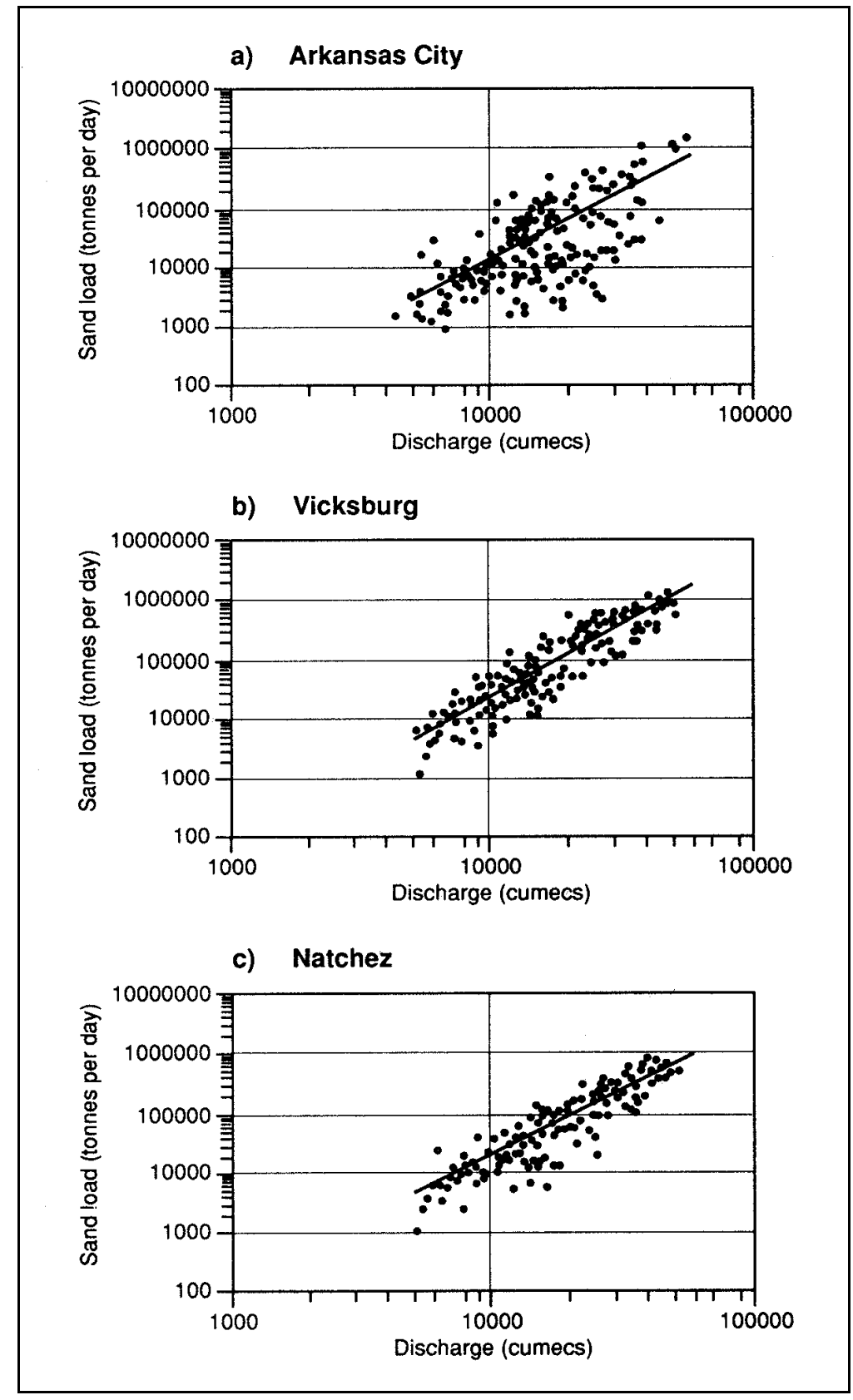

Figure 3. Sediment rating curves for the period 1969-1979 at (a) Arkansas City, (b) Vicksburg, and (c) Natchez

\section{Table 1}

Sediment Rating Curve Equations

\begin{tabular}{||l|l|l|l||}
\hline \hline Station & Coefficient & Exponent & $\begin{array}{l}\text { Coefficient of } \\
\text { Determination }\left(r^{2}\right)\end{array}$ \\
\hline \hline Arkansas City & 0.0000118 & 2.27 & 0.55 \\
\hline Vicksburg & 0.00000513 & 2.42 & 0.82 \\
\hline Natchez & 0.0000408 & 2.17 & 0.77 \\
\hline
\end{tabular}


multiplying this value by the frequency of each increment in days. For example, at Natchez an observed mean daily flow of $30,680 \mathrm{~m}^{3} / \mathrm{s}$ would be assigned to the $31,000 \mathrm{~m}^{3} / \mathrm{s}$ flow increment. According to the sediment rating equation for Natchez, a flow of $31,000 \mathrm{~m}^{3} / \mathrm{s}$ transports 240,000 tons of sand each day. During the 33-year period between 1950 and 1982, flows in this increment occurred on 189 days. Therefore, flows within this increment were responsible for transporting $45.4 \times 10^{6}$ tons of sand during the 33 -year period. This procedure was repeated for all flow increments and the total amount of sediment was then plotted against its respective flow increment (Figure 4).

To illustrate the relative amounts of sediment moved by various ranges of flow, cumulative sediment load curves were developed for each station. This was accomplished by calculating the percentage of the sediment load moved by each flow increment and summing the results from the smallest to largest flows, producing a cumulative curve that shows the percentage of sediment moved at or below a given discharge over the entire period of record (Figure 5).

\section{Determination of Top of Bank and Mid-Channel Bar Elevations}

Top of bank elevations were determined by careful examination of 1973-1975 cross sections. Care was taken to ensure that top of bank points represented the true, natural top of bank elevation and did not reflect some anomalous condition due to either the influence of an engineering structure such as a road embankment and levee, or the presence of a natural river bluff.

Elevations of the tops of the mid-channel bars were determined from the 1962-1964, 1973-1975, and 1988-1989 hydrographic surveys. Although some subjectivity was involved in the determination of the top of bank elevations, this was small because the break of slope at the bank top was readily discernible from the cross sections. However, in the case of the mid-channel bars, there was uncertainty about the elevation that most accurately reflects the bar top. The simplest method would be to select the highest elevation encountered on the bar, but it was observed that this often corresponded to a localized high area covering a very small portion of the bar surface. A better representation of the depositional surface reflecting the top of the bar that was not unduly influenced by small, localized high spots was determined from a cumulative plot showing the percentage of total area below a given contour. An example, for the Kentucky Bar, is shown in Figure 6. The zero contour elevation, which corresponds to the elevation of low water reference plane (LWRP), was selected as the base elevation. The elevation below which 95 percent of the area is under water was selected to represent the top of the mid-channel bar.

This procedure attempted to remove subjectivity from the analysis and produce reproducible results. However, some uncertainties remain. First, there are the basic limitations of the survey data. In many instances the channel 


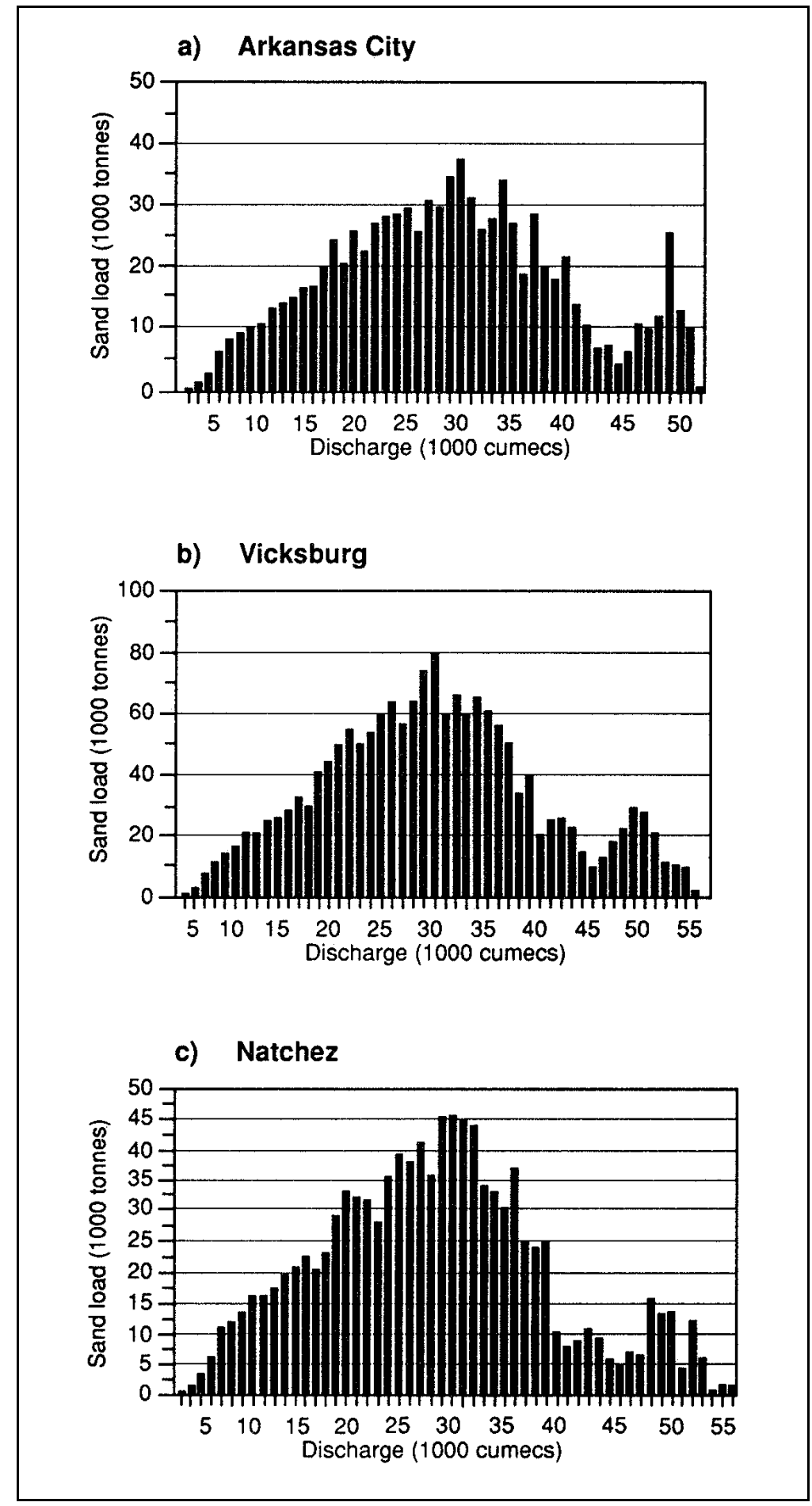

Figure 4. Dominant discharge distributions for time period 1950-1982 for (a) Arkansas City, (b) Vicksburg, and (c) Natchez 


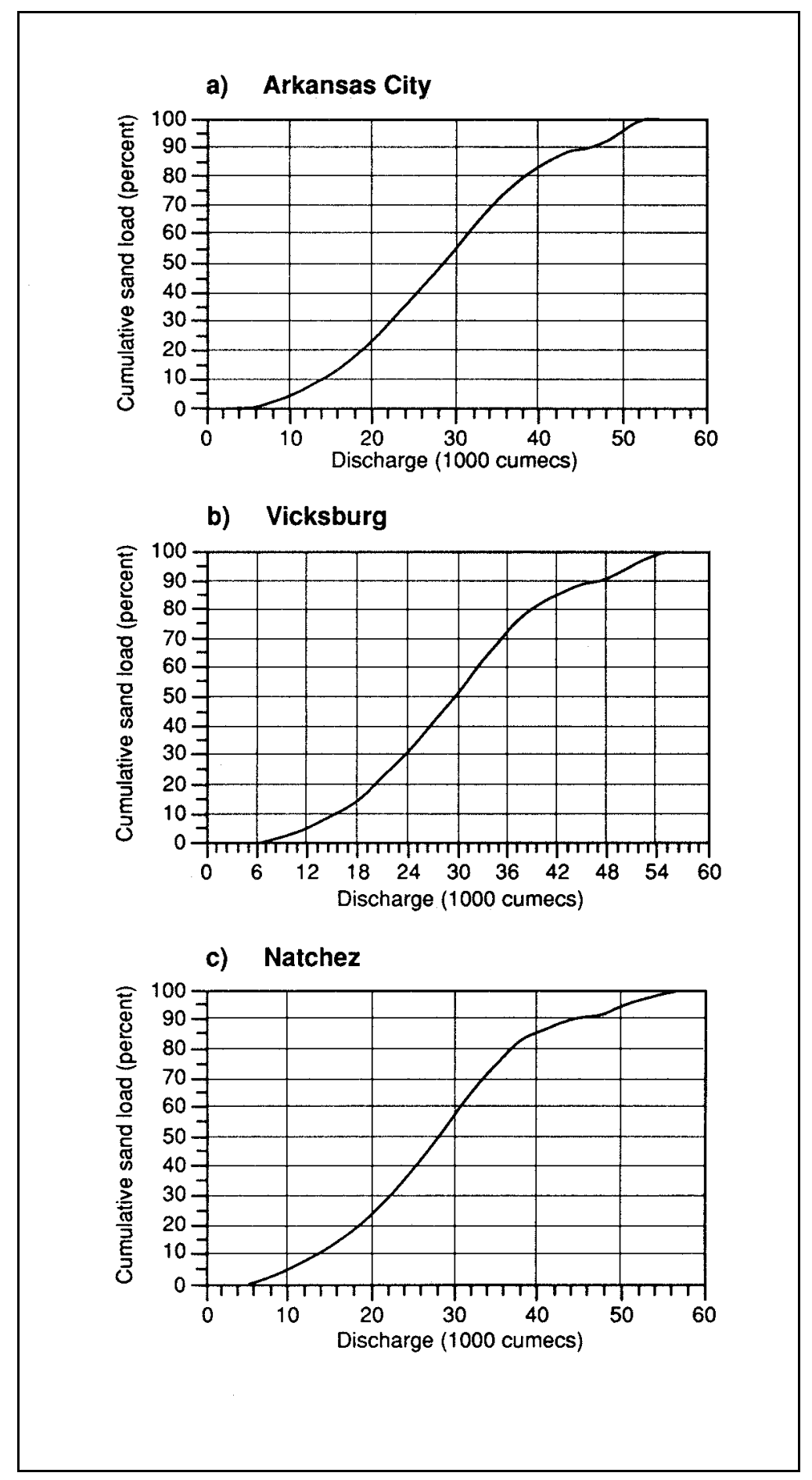

Figure 5. Cumulative sediment load curves for time period 1950-1982 for (a) Arkansas City, (b) Vicksburg, and (c) Natchez 


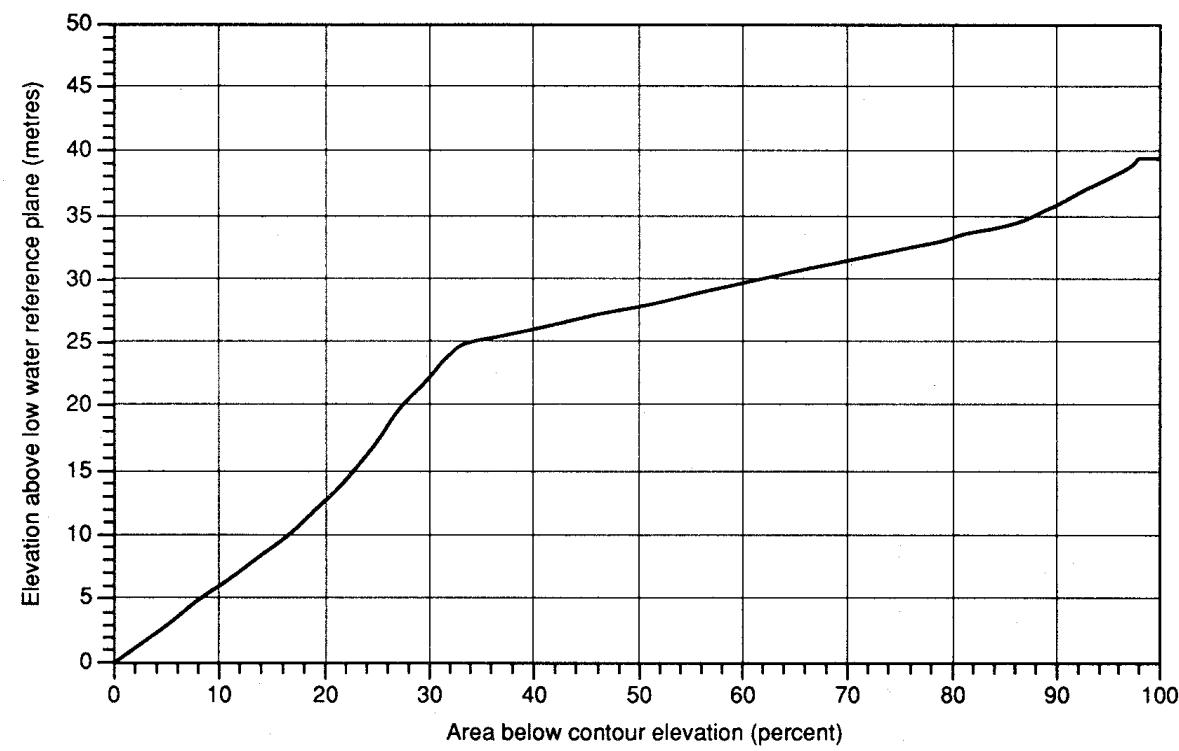

Figure 6. Area-elevation curve for a typical mid-channel bar in the study reach. Data taken from Kentucky Bar at river kilometer 840 for 1988-1989 hydrographic survey

cross-sections were not extended across the mid-channel bars, but rather contours were established based on photogrammetric techniques. In these instances, there may be some uncertainty as to the accuracy of the surveys compared with actual ground surveys. Secondly, it must be recognized that these bars are dynamic features and may be in various phases of evolution at the time of different surveys. Thirdly, there is the complicating factor of the influence of dikes and revetments on the morphology of the bars. 


\section{Discussion}

\section{Effective Discharge Analyses}

The results of the magnitude-frequency analyses for the Arkansas City, Vicksburg, and Natchez gauges are shown in Figures 4a, 4b, and 4c, respectively. These histograms show the total amount of sediment transported in each flow increment during the 33-year period. Although the amounts transported by a given flow increment vary slightly from station to station, each of the distributions is unimodal, with its peak indicating a dominant (or effective) discharge of about $30,000 \mathrm{~m}^{3} / \mathrm{s}$.

Flow-duration curves for each station indicate that this discharge is equaled or exceeded about 13 percent of the time and from a flow-frequency perspective, based on a partial duration series, the dominant discharge has a return period equal to or just less than 1 year. This is consistent with the concept of Wolman and Miller (1960) and the findings of Leopold, Wolman, and Miller (1964) that the return period for the dominant discharge is 1 to 2 years.

\section{Cumulative Sediment Transport}

Although the effective discharge analyses define the dominant discharge, Figure 4 also shows that there is a range of flows that contributes significantly to the overall sediment transport at each gauging station. A cumulative analysis of the sediment transport was conducted to determine limits of this "effective range" of flows (Figure 5). Although there are minor differences in the shapes of the curves, they all exhibit a similar form and each curve can be divided into three zones.

Zone 1 represents the steepest segment of the cumulative curves. This zone generally extends from about $17,000 \mathrm{~m}^{3} / \mathrm{s}$ to about $40,000 \mathrm{~m}^{3} / \mathrm{s}$ and represents the zone of maximum sediment transport for each increment of discharge. The flows in this zone are responsible for transporting about 70 percent of the sediment load. Zone 2 encompasses the low flow regime, extending up to about $17,000 \mathrm{~m}^{3} / \mathrm{s}$. In this zone, only about 15 percent of the sediment load is moved. 
Zone 3 represents the high flow regime above about $40,000 \mathrm{~m}^{3} / \mathrm{s}$, where the slope of the cumulative curve flattens and is also responsible for only 15 percent of the sediment load.

Based on this analysis, the effective range of flows for the Lower Mississippi River occurs between about 17,000 and $40,000 \mathrm{~m}^{3} / \mathrm{s}$. The lower limit of the effective range of flows $\left(17,000 \mathrm{~m}^{3} / \mathrm{s}\right)$ corresponds to the mean annual flow, is equaled or exceeded 40 percent of the time and has a return period of about 0.5 year (based on partial duration series). The upper limit $\left(40,000 \mathrm{~m}^{3} / \mathrm{s}\right)$ is equaled or exceeded 3 percent of the time and has a return period of about 5 years.

Figure 7 shows the water surface profiles for the effective range of flows, for high water and for low water. In this plot, the water levels for 17,000, 30,000, and $40,000 \mathrm{~m}^{3} / \mathrm{s}$ are shown to represent the effective range of flows. For the low-flow condition, the LWRP is shown because it reflects about the lowest stages encountered during the period of record. The 50-year water level $\left(58,000 \mathrm{~m}^{3} / \mathrm{s}\right)$ was selected for high water because it provides an upper envelope for the highest flows recorded during the period of record.

The effective range of flows transports 70 percent of the sediment load and occurs over a stage range of about $7.3 \mathrm{~m}$ (Figure 7). In contrast, there is a 6-m stage range between the LWRP and $17,000 \mathrm{~m}^{3} / \mathrm{s}$ water surface profile, but only

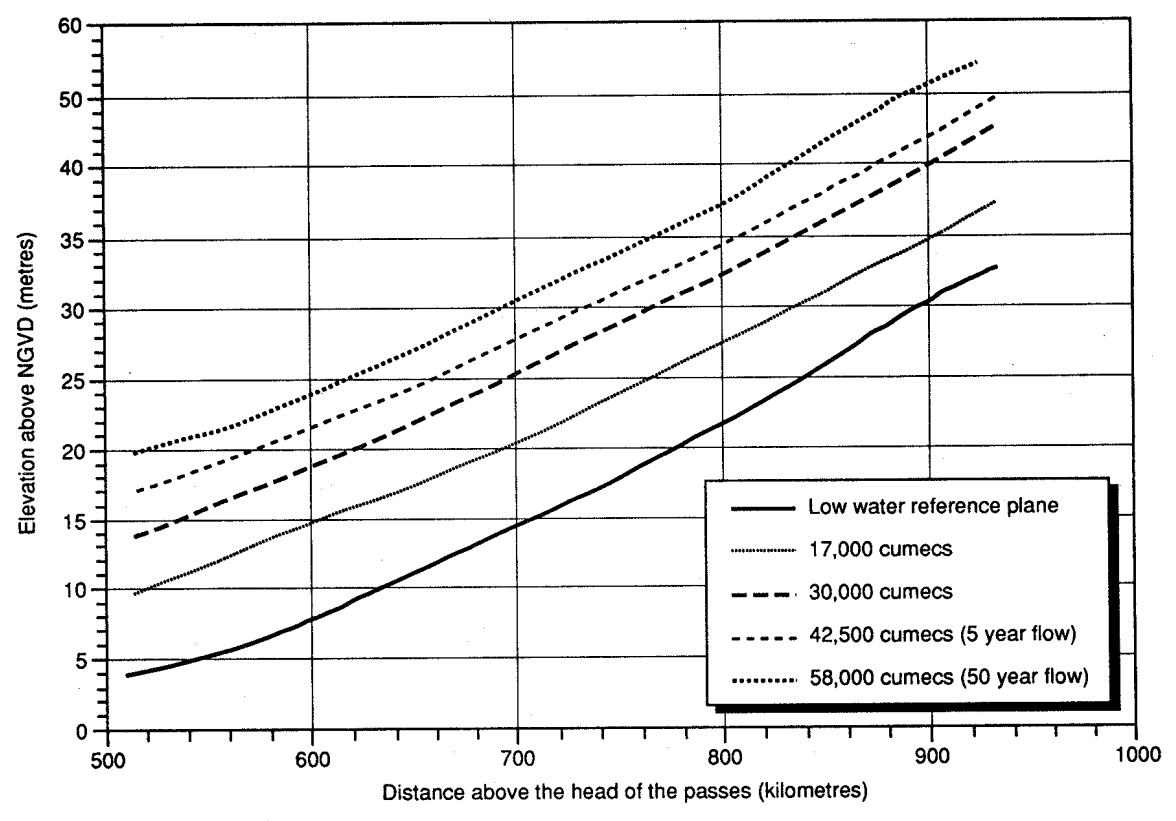

Figure 7. Water surface profiles for selected discharges in the Lower Mississippi River 
about 15 percent of the sediment load is moved in this range. Similarly, only 15 percent of the sediment load is moved in the 3-m stage range between 40,000 and $58,050 \mathrm{~m}^{3} / \mathrm{s}$. It should also be recognized that this upper range of flows occurs in an overbank situation, where stage increases with increased discharges are comparatively lower than those occurring for within-bank conditions.

\section{Impact of a Major Flood Event}

One of the criticisms of the dominant discharge concept is that major flood events are not properly accounted for by relatively short periods of record. To investigate this criticism, the magnitude-frequency analysis was repeated for the Natchez station with the Corps of Engineer's "Project Flood" added to the 33 -year period of record. This is an extreme event with an instantaneous peak discharge of $76,460 \mathrm{~m}^{3} / \mathrm{s}$ and flows in excess of $56,500 \mathrm{~m}^{3} / \mathrm{s}$ being sustained for 2 months. Including this extremely high flood does alter the shape of the overall sediment transport curve (Figure 8), which shows a secondary peak resulting from this extreme event. However, this new peak is small compared with the primary peak of the dominant discharge, which still occurs at about $30,000 \mathrm{~m}^{3} / \mathrm{s}$. The limited impact of the design flood is further illustrated in Figure 9.

Although the shape of the cumulative curve is altered, particularly at higher flows, and 8 percent more sediment is moved by flows above $40,000 \mathrm{~m}^{3} / \mathrm{s}$, the dominant discharge and effective range of flows remain essentially unchanged. It can therefore be concluded that the 33-year period of record from 1950 to 1982 is sufficiently long that the occurrence of an extreme high flow does not significantly affect the results.

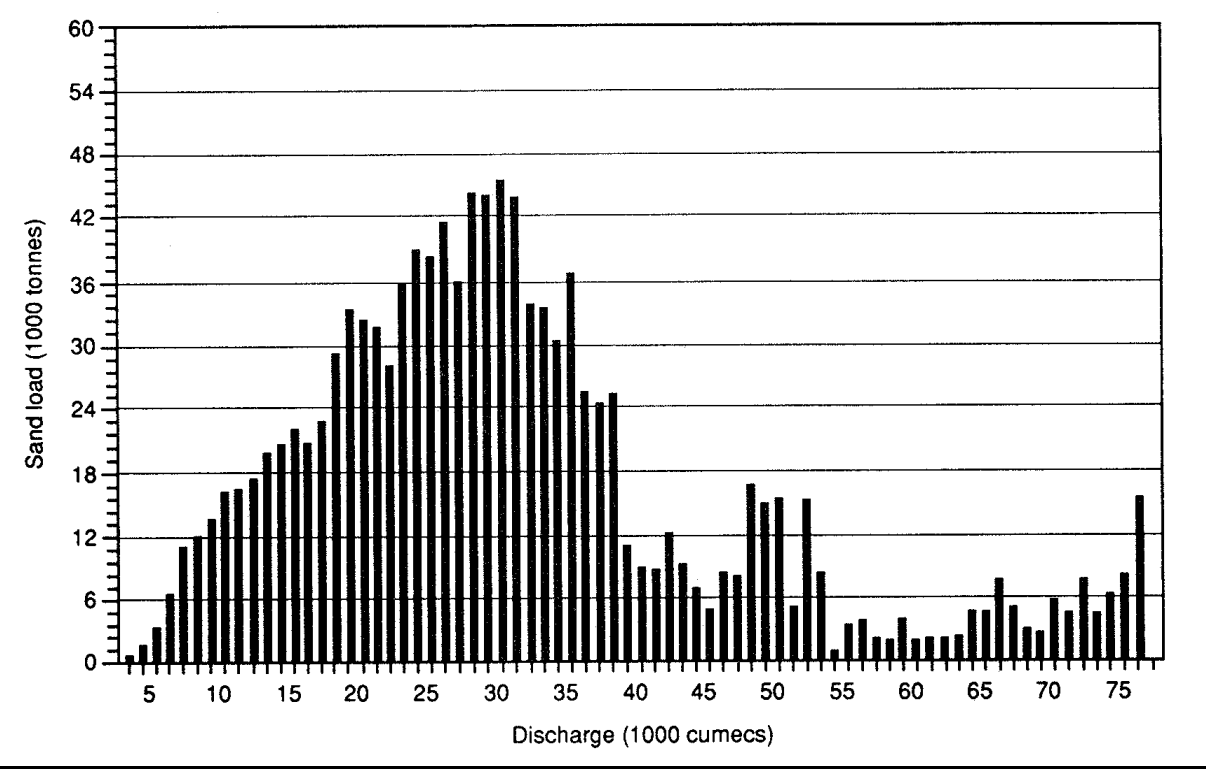

Figure 8. Dominant discharge distributions for Natchez including the Corps of Engineer's Project Flood 


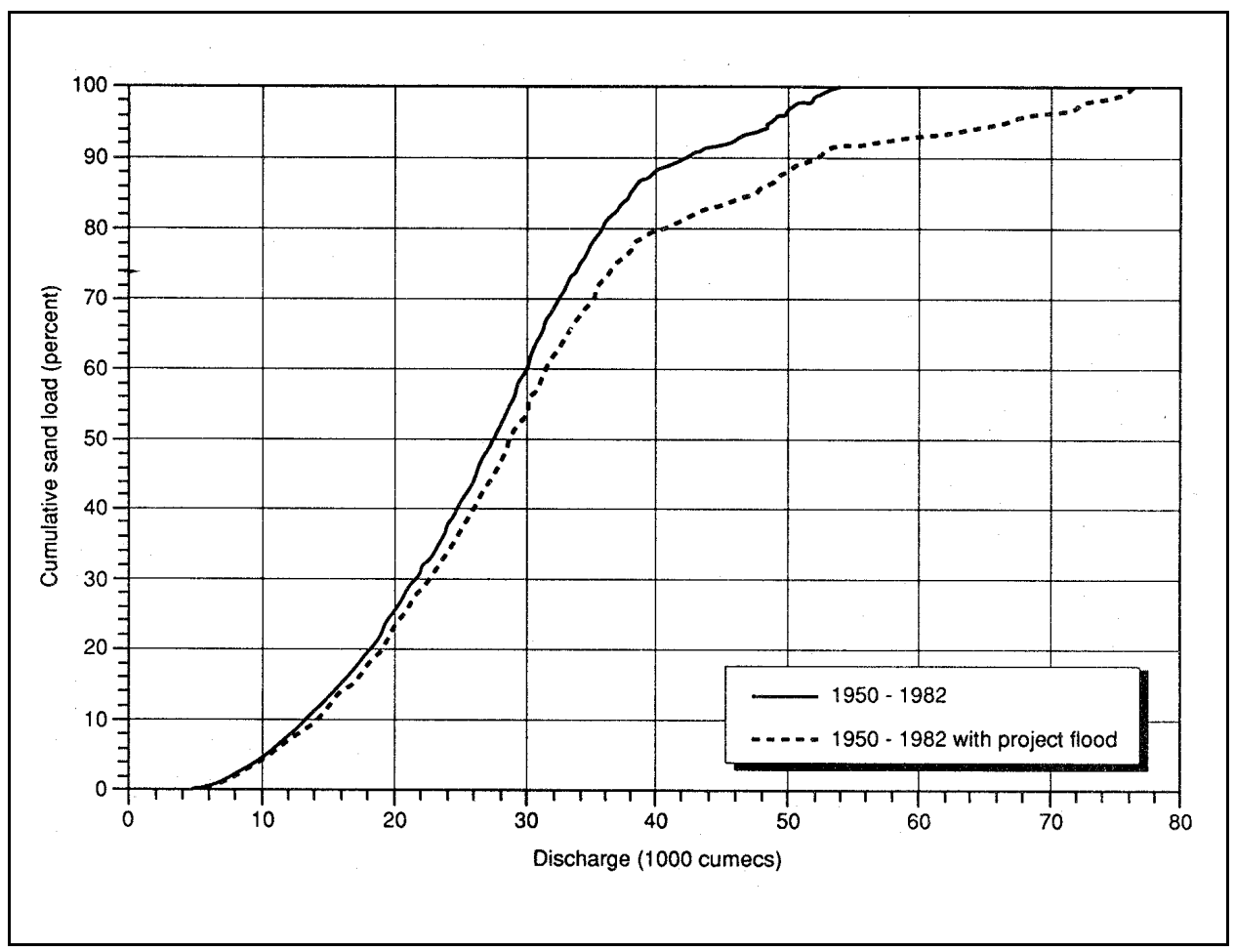

Figure 9. Cumulative sediment load curve for Natchez including the Corps of Engineers' Project Flood

This finding cannot be taken to imply that the project flood is insignificant. On the contrary, if this flood were to occur, there would certainly be significant erosional and depositional problems, as well as marked changes in the local channel morphology. However, this event has an extremely long return period, which is much longer than the relaxation time for its morphological effect.

Hence, over long periods, the effective range of flows remains the primary factor in shaping the channel.

\section{Morphological Expressions of the Dominant Discharge and Effective Range of Flows}

Implicit in the magnitude-frequency concept is the assumption that the flows transporting most of the sediment also accomplish the most work in forming the channel and determining its major morphological characteristics. If this is true, then there should be some morphological expression of the dominant discharge and range of effective flows in the form of the channel. For example, dominant discharge has often in the past been found to be equivalent to bank-full discharge, so that the channel capacity and bank-top elevation represent the morphological expressions of dominant flow in the cross section (Leopold, Wolman, and Miller 1964; Hey 1975). 
For the Lower Mississippi River, a long channel plot of top of bank elevations taken from the 1973-1975 hydrographic survey reveals that this parameter is highly variable and can differ by $3 \mathrm{~m}$ or more between adjacent cross sections (Figure 10). This variation in top of bank elevations is not unusual for alluvial rivers and simply reflects the highly dynamic and variable nature of the fluvial system. With this amount of variation, it is difficult to identify a single flow event that fully represents top of bank conditions. However, as shown in Figure 10, there is a strong correlation between the upper and lower bounds of the top of bank scatter and the upper bound of the effective range of flows and the dominant discharge, respectively.

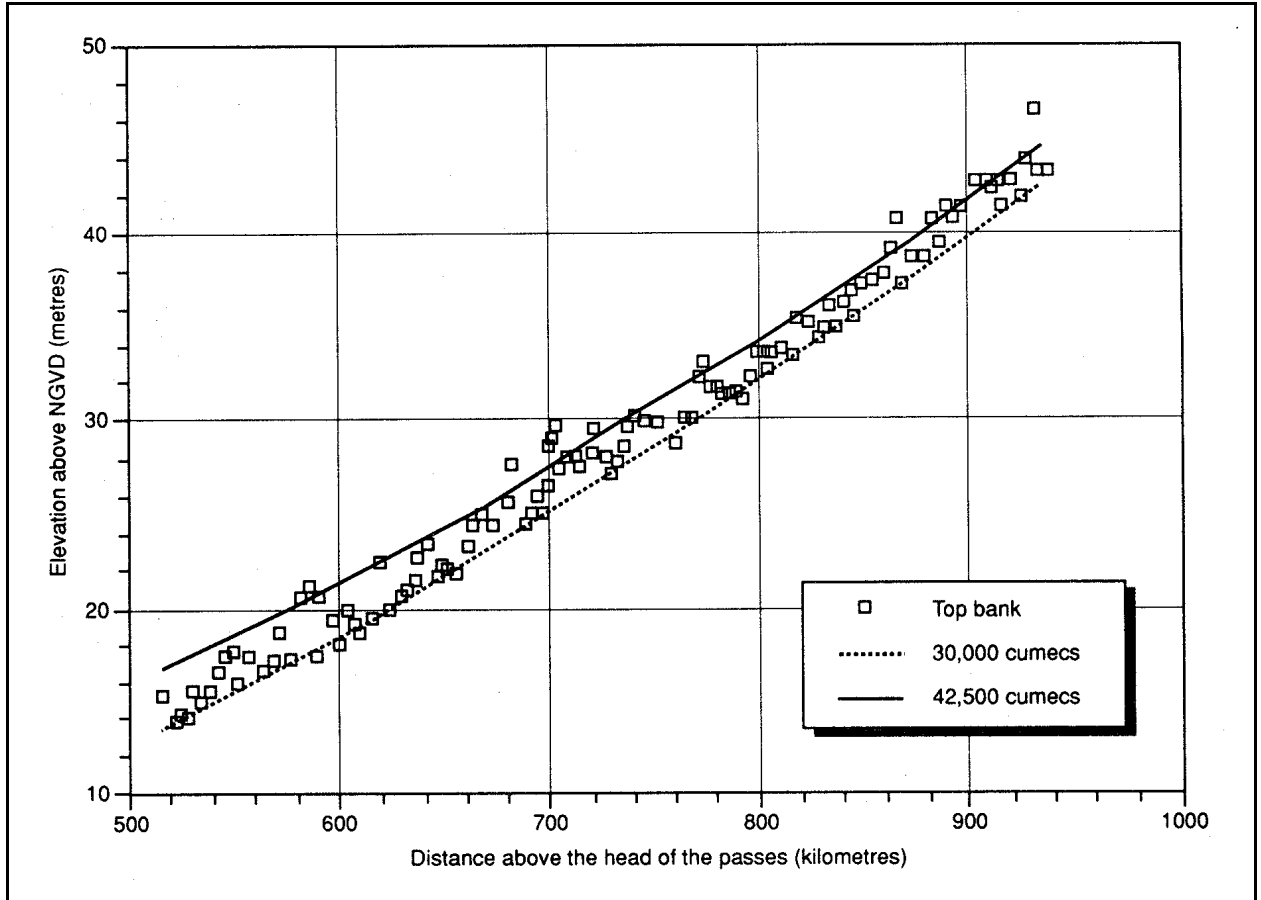

Figure 10. Long-channel variation in top-bank elevations in the study reach

The fact that the water surface profile for the dominant discharge $\left(30,000 \mathrm{~m}^{3} / \mathrm{s}\right.$ in Figure 10) forms a good lower bound to the scatter of bank elevations indicates that the capacity of the channel is adjusted just to contain all flows up to and including the dominant discharge. As stages increase above this level, flow begins to spill out over the banks at more and more locations. This leads to changes in the flow pattern and the expansion of zones of interaction between in-bank and overbank flows that produce significant energy losses, higher flow resistance, and radically altered distributions of sedimentation.

In Figure 10, the upper boundary to scatter in the top of bank elevations corresponds well to the upper limit of the effective range of flows--that is, the $40,000-\mathrm{m}^{3} / \mathrm{s}$ water surface profile. There are only a few isolated locations where top of bank elevations are higher than this. Therefore, the upper limit of the effective range of flows forms an upper boundary to the top of bank elevations, 
reflecting a close link between the range of effective flows that transport the bulk of the sediment load and the upper limit of bank accretion. This does not suggest that the flow regime about $40,000 \mathrm{~m}^{3} / \mathrm{s}$ does not contribute to channel and floodplain development, but that the influence of the large events is decreased due to their rarity and extremely short duration. It can also be observed that in the upper reaches of the study area top of bank elevations are a little higher, relative to the $40,000-\mathrm{m}^{3} / \mathrm{s}$ water surface profile, than further downstream. This reflects the continuing water level lowering in the upper reach of the river (Elliott, Rentschler, and Brooks 1990).

A second prominent morphological feature that may be related to dominant discharge and effective range of flows is the height to which mid-channel bars grow through accretion. Figure 11 shows that mid-channel bar elevations generally occur in the lower half of the effective range of flows, somewhere between the $17,000-$ and $30,000-\mathrm{m}^{3} / \mathrm{s}$ water levels. This suggests that dominant discharge corresponds to both the upper bound of "bar-full" and the lower bound of bankfull flows for the Lower Mississippi. The submergence of mid-channel bars leads to the conversion of separate low-flow anabranches into a singlethread channel. This will result in decreased energy losses at bifurcations and confluences, increased sediment transport capacity, and increased sediment availability from the inundated bars. Hence it is perhaps not surprising that this bar-topping stage coincides with the dominant discharge. The finding that dominant discharge corresponds to bar-full stage is in agreement with the results of magnitude-frequency analysis of the Brahmaputra River, Bangladesh, a very large braided river (Thorne, Russell, and Alan 1993).

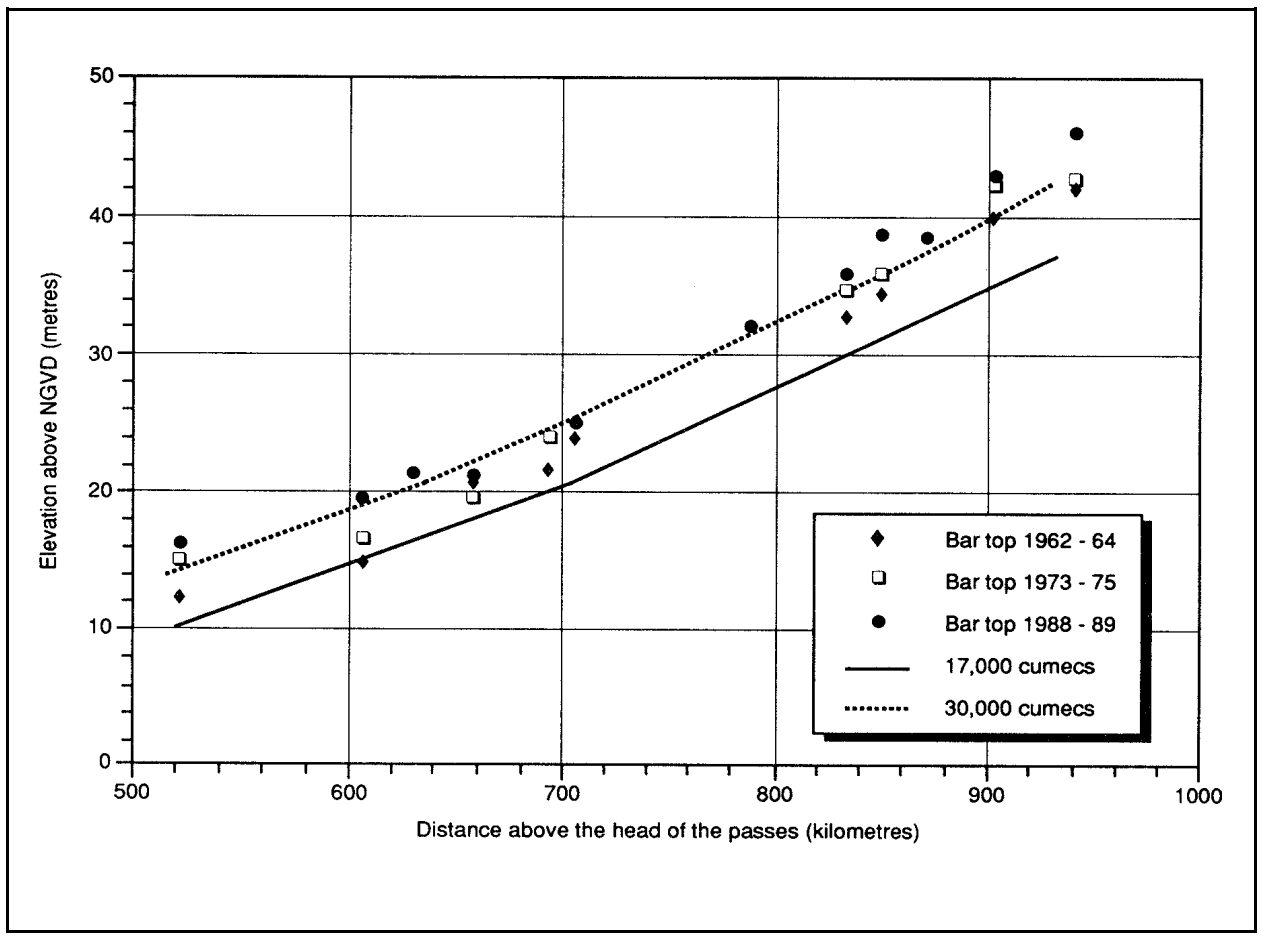

Figure 11. Long-channel variation in elevations of mid-channel bars in the study reach 
The data in Figure 11 also indicate that the bar-top elevations in 1988-1989 were generally higher than in 1962-1964 and 1973-1975. Bar growth cannot be due to a general aggradational trend in the river because, although the specific gauge record for Natchez does indicate aggradation, the records for Vicksburg and Arkansas City show no such trend, despite also experiencing increasing bar elevations (Winkley 1982). For the most part, the 1988-1989 bar-top elevations correspond to the lower range of top of bank elevations and are close to the dominant discharge water surface profile, whereas the bar tops in 1962-1964 and 1973-1975 were significantly lower. This seems to suggest that as the midchannel bars mature, the elevation of the bar tops approaches that of dominant discharge and the surrounding top of banks. This evolutionary process is understandable, given the constrained condition of the river, which prohibits channel shifting and lateral accretion, and therefore encourages in-channel, vertical accretion on bars. However, it must be noted that the difference in the elevations between 1962-1964 and 1988-1989 is generally only about 1.5-3 m, and given the survey limitations and the uncertainties in the bar-top determination procedure, these results should be considered preliminary. A more detailed analysis of the evolution of these bars in needed to confirm that this trend is correct. 


\section{Engineering Applications}

Recognizing the dominant discharge and effective range of flows responsible for forming the salient features of the channel morphology has important applications to river engineering, particularly in determining stable channel geometries and planforms and designing hard structures for river training and stabilization.

River engineers are often required to make design decisions without having a complete understanding of the fluvial system with which they are dealing. This can lead to uncertainty about the response of the river to engineering work. The primary goals of the River Engineering Branch of the Corps of Engineers, Lower Mississippi Valley Division, are to document the long- and short-term morphological trends in the river and to monitor the channel response to engineering interventions. Developing an understanding of the dominant or channel-forming flow, the effective range of flows, and their relationships with channel morphology remain central elements of river engineering studies. With this in mind, the results of the magnitude-frequency analysis may be summarized as follows.

The magnitude-frequency analysis reported here has shown that the individual flow increment responsible for transporting the most sediment in the long term, often referred to as the dominant or effective discharge, is about $30,000 \mathrm{~m}^{3} / \mathrm{s}$ for the Lower Mississippi River within the study reach. This is a relatively moderate flow with a return period of about 1 year, which is equaled or exceeded about 13 percent of the time. The effective range of flows was identified between about 17,000 and $40,000 \mathrm{~m}^{3} / \mathrm{s}$, within which about 70 percent of the long-term sediment load is transported. There was a strong correlation between the top of bank elevations throughout the study reach, the dominant discharge, and the effective range of flows. The dominant discharge forms a lower boundary to top of bank elevations where overbank flows are just beginning to occur. The water surface profile for $40,000 \mathrm{~m}^{3} / \mathrm{s}$ forms the upper boundary, representing the maximum elevation for top of banks. The top elevations of the mid-channel bars are usually lower than top of bank elevations and generally fall within the lower half of the effective range of flows, between the dominant discharge $\left(30,000 \mathrm{~m}^{3} / \mathrm{s}\right)$ and the $17,000-\mathrm{m}^{3} / \mathrm{s}$ water surface profile. There is some indication that as the mid-channel bars mature, the elevation of the bar tops approaches the lower boundary of the surrounding top banks, suggesting that they are adjusting to the dominant discharge and the constraints imposed by channel training works. 
This information has been found to be useful in relation to several aspects of river engineering, particularly in the design of river training structures. This can be illustrated by two particular engineering applications.

First, when planning river training and stabilization works, the need to harmonize with natural periodicities in the channel morphology is now accepted. Experience shows that the selection of a good alignment to the channel, especially through the correct spacing of bends and crossings, drastically reduces the amount of dredging that is necessary to maintain a channel that is stable, provides an adequate navigation depth, and has sufficient capacity to convey sediment through the system (Winkley 1982). Determining the dimensions of the trained channel and, most importantly, the spacing of crossings between bends, requires reliable estimates of the dominant discharge and the range of effective flows. Magnitude-frequency analysis to establish design parameters therefore continues to be of crucial importance to sustainable channel stabilization.

Second, a new design procedure for stone dike contraction structures on the Mississippi River has been formalized on the basis of hydraulic geometry analysis linked to an appreciation of process-form controls of channel morphology (Lamb and Ethridge 1990). This procedure is used to determine the appropriate size and elevation of stone dikes constructed to preserve an adequate low water navigation channel while not impeding flood flows. It is based on empirical relations between the width of the navigation channel and that of the overall channel, and between the proportions of the total conveyance within the navigation channel and outside that channel, above the elevation of the dikes. Key components in this design procedure are determining the top of bank width and elevation, which are essential for the conveyance calculations. Top of bank width and elevation are selected with reference to the water surface profiles for the dominant discharge and for the effective range of flows, where the preponderance of sediment transport occurs.

These two examples illustrate the value of magnitude-frequency analyses for determining the dominant discharge and effective range of flows. There are tangible benefits for river engineering and channel design on the Mississippi River, as well as on other alluvial rivers around the world. 


\section{References}

Ackers, P., and Charlton, F. G. (1970). "Meander geometry arising from varying flows," J. Hydrol. 11, 230-252.

Bagnold, R. A. (1966). "An approach to the sediment transport problem from general physics," USGS. Prof. Pap. 422-I, 1-37.

Biedenharn, D. S., Little, C. D., and Thorne, C. R. (1987). "Magnitude and frequency analysis of large rivers." Hydraulic Engineering Proceedings of the National Conference on Hydraulic Engineering. R. M. Ragan, ed., American Society of Civil Engineers, Williamsburg, PA, 782-787.

Elliott, C. M., Rentschler, R. E., and Brooks, J. (1990). "Low water response of the Lower Mississippi River." Proceedings of the $5^{\text {th }}$ Federal Interagency Sedimentation Conference. Vol 1, U.S. Federal Energy Regulatory Commission, Washington, DC, 4-16-4-23.

Hey, R. D. (1972). "Analysis of some of the factors influencing the hydraulic geometry of alluvial channels," unpublished Ph.D. diss., Univ. Cambridge.

Hey, R. D. (1975). "Design discharge for natural channels.” Science, technology and environmental management. R. D. Hey and T. D. Davies, ed., Saxon House, Farnborough, 73-88.

Hey, R. D. (1982). "Design equations for mobile gravel-bed rivers." Gravelbed rivers. R. D. Hey, J. C. Bathurst, and C. R. Thorne, ed., Wiley, Chichester, 553-574.

Hey, R. D., and Thorne, C. R. (1986). "Stable channels with mobile gravel beds," J. Hydr. Engin. 112, 671-689.

Inglis, C. C. (1949). "The behavior and control of rivers and canals," Res. Publ. 13, Central Water Power, Irrigation and Navigation Research Station, Poona. 
Lamb, M. S., and Thridge, L. T. (1990). "Sediment management of the Mississippi." Proceedings of the $5^{\text {th }}$ Federal Interagency Sedimentation Conference. Vol 1, U.S. Federal Energy Regulatory Commission, Washington, DC, 1-1-1-8.

Leopold, L. B., Wolman, M. G., and Miller, J. P. (1964). Fluvial processes in geomorphology. Freeman, San Francisco, CA.

Lewin, J. (1978). "Meander development and flood plain sedimentation: A case study from mid- Wales," Geol. J., 13, 25-36.

Richards, K. S. (1982). Rivers: Form and process in alluvial channels. Methuen, London.

Robbins, L. G. (1977). "Suspended sediment and bed material studies on the Lower Mississippi River," Potamology Investigations Rep.300-1, U.S. Army Engineer District, Vicksburg, MS.

Summerfield, M. (1991). Global geomorphology. Longman, Harlow.

Thorne, C. R. (1982). "Processes and mechanisms of bank erosion." Gravelbed rivers. R. D. Hey, J. C. Bathurst, and C. R. Thorne, ed., Wiley, Chichester, 227-272.

Thorne, C. R., Hey, R. D., and Bathurst, J. C. (ed.) (1987). Sediment transport in gravel-bed rivers. Wiley, Chichester.

Thorne, C. R., Russell, R. P. G., and Alam, M. K. (1993). "Planform pattern and channel evolution of the Brahmaputra River, Bangladesh," Braided rivers. Spec. Publ. Geol. Soc. London No.75, 257-276.

Toffaleti, F. B. (1968). "A procedure for computation of the total river sand discharge and detailed distribution, bed to surface," Tech. Rep. No.5, Committee on Channel Stabilization, U.S. Army Corps of Engineers, Vicksburg, MS.

Williams, G. P. (1978). "Bankfull discharge of rivers," Wat. Resour. Res. 14, 1141-1154.

Winkley, B. R. (1982). "Response of the Lower Mississippi to training and realignment." Gravel-bed rivers. R. D. Hey, J. C. Bathurst, and C. R. Thorne, ed., Wiley, Chichester, 659-682.

Wolman, M. G., and Leopold, L. B. (1957). "River flood plains: Some observations on their formation," USGS Prof. Pap. 282C, 87-107.

Wolman, M. G., and Miller, J. P. (1960). "Magnitude and frequency of forces in geomorphic processes," J. Geol. 68, 54-74. 


\section{REPORT DOCUMENTATION PAGE}

Public reporting burden for this collection of information is estimated to average 1 hour per response, including the time for reviewing instructions, searching existing data sources, gathering and maintaining

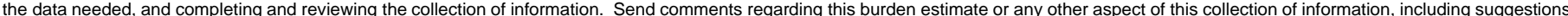

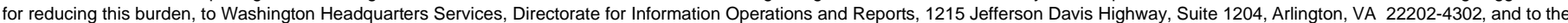
Office of Management and Budget, Paperwork Reduction Project (0704-0188), Washington, DC 20503.
1. AGENCY USE ONLY (Leave blank)
2. REPORT DATE
August 1999
3. REPORT TYPE AND DATES COVERED
Final report

\section{TITLE AND SUBTITLE}

5. FUNDING NUMBERS

Magnitude-Frequency Analysis of Sediment Transport in the Lower

Mississippi River

6. AUTHOR(S)

David S. Biedenharn, Charles D. Little, Colin R. Thorne

\section{PERFORMING ORGANIZATION NAME(S) AND ADDRESS(ES)}

U.S. Army Engineer Waterways Experiment Station

3909 Halls Ferry Road, Vicksburg, MS 39180-6199;

8. PERFORMING ORGANIZATION REPORT NUMBER

Miscellaneous Paper CHL-99-2

U.S. Army Corps of Engineers, Vicksburg District

P. O. Box 60, Vicksburg, MS 39180-6199;

University of Nottingham

Nottingham, NG7 2RD, UK

9. SPONSORING/MONITORING AGENCY NAME(S) AND ADDRESS(ES)

U.S. Army Corps of Engineers

Washington, DC 20314-1000

10. SPONSORING/MONITORING AGENCY REPORT NUMBER

11. SUPPLEMENTARY NOTES

Available from National Technical Information Service, 5285 Port Royal Road, Springfield, VA 22161.

12a. DISTRIBUTION/AVAILABILITY STATEMENT

12b. DISTRIBUTION CODE

Approved for public release; distribution is unlimited.

\section{ABSTRACT (Maximum 200 words)}

Magnitude-frequency analysis of gauging station records (1950-1982) on the Lower Mississippi shows that there is a clearly defined dominant flow of about $30,000 \mathrm{~m}^{3} / \mathrm{s}$. This lies within an effective range of channel-forming flows between 17,000 and $40,000 \mathrm{~m}^{3} / \mathrm{s}$, which are responsible for transporting a disproportionately large percentage of the sediment load. The 33-year period of record is sufficiently long that the occurrence of an extreme high-flow event does not significantly change these results. Hydrographic survey data, long-profile records, and stage-discharge relationships from calibrated one-dimensional flow models indicate that the dominant discharge corresponds to "bar-full" discharge on the Lower Mississippi and that the effective range of flows occurs between the stage that just tops mid-channel bars and that which significantly overtops the bank. Historical trends in bar growth suggest that bar-top elevations have generally risen to the dominant flow elevation over the last 30 years.

\section{SUBJECT TERMS}

Alluvial rivers

Magnitude-frequency analysis
Mississippi River

River morphology
15. NUMBER OF PAGES

31

16. PRICE CODE

\begin{tabular}{|l|c|c|}
\hline $\begin{array}{l}\text { 17. SECURITY CLASSIFICATION } \\
\text { OF REPORT }\end{array}$ & $\begin{array}{c}\text { 18. SECURITY CLASSIFICATION } \\
\text { OF THIS PAGE } \\
\text { UNCLASSIFIED }\end{array}$ & $\begin{array}{c}\text { 19. SECURITY CLASSIFICATION } \\
\text { OF ABSTRACT }\end{array}$ \\
\hline UNCLASSIFIED & \\
\hline
\end{tabular}

NSN 7540-01-280-5500
Standard Form 298 (Rev. 2-89) Prescribed by ANSI Std. Z39-18 298-102 